\title{
Abandonment and accessibility in railway historical buildings: Central do Brasil and Leopoldina Railstation
}

\author{
Brasil, C.C.G., Costa, A.M., Castañon, J.A.B. \\ Department of Transport, Federal University of Juiz de Fora, Engineering Faculty, Room 4156 Campus of UFJF, \\ Juiz de Fora, Minas Gerais, Brasil
}

\begin{abstract}
This paper aims to demonstrate the evolution of a study in the city of Juiz de Fora-MG, whose objective is the assessment of areas of train station in relation to the inclusion of people with disabilities and consequently promote the historical and cultural heritage of this city. The railway buildings are important landmarks in the history of the city and its surroundings was formed the first core of urban development. Because this building was of the early nineteenth century, these were not designed to assist people with disabilities, in effect, we observed that the buildings are being underutilized. The difficulty of insertion of incentive policies is therefore not due to the commitment by the majority, making the deployment of new access.
\end{abstract}

Keywords: Acessibility, cultural heritage, urban mobility, social inclusion.

\section{Introduction}

This paper demonstrates the evolution of research conducted in Juiz de Fora/MG, whose objective is the assessment of areas of the city railway station, aiming to let people know the historical and cultural heritage of this city. Make use this study to facilitate a possible solution to the problem of abandonment of the historic rail buildings in the city, especially the Railstations of the Leopoldina Railway - LR- and Central do Brazil - CB, as well as discussing the issue of accessibility to them. At the end of the study is expected to safeguard the memory of the railroad and contribute to future research on understanding how the urban spaces that encourage such research, contributing to the formation of built environments that provide quality of life to the user of the city.

The railway buildings are important landmarks in the history of the city [1], formed the first urban core development, located at Praça Dr. João Penido, popularly known as Station Square. It is located in the central area, popularly called "parte baixa" or "underground", between Marechal Deodoro and Halfed Streets. The square came up with the construction of the railstation Dom Pedro II, was inaugurated in the early nineteenth century, and was one of the entrances to the city. That time, beginning of the industrial period, the railway was the main access road to the Juiz de Fora, thus, the square represents the heyday of industrialization of the city. The city developed around it, the buildings remain today, creating an area of high economic growth and dynamism [2], where hotels were built to meet the demand generated. Near the railroad was concentrated commercial and industrial development. Currently, this space houses the main historic hub of the city.

\section{From peak to decay}

People used the railroad as transportation and had other benefits with this service, so the railroads resonated strongly in the economic, social, political and military society. Nowadays, we see that the buildings of E.F.C.B. (Central do Brasil Railway) and E.F.L. (Leopoldina Railway) are being underutilized. This work aims to upgrade the buildings through research and evaluation on the accessibility of space, given that "the historic areas (...) is the living presence of the past that gave way, and (...) for that acquire a value and an additional human dimension" [3].

Because it is a building of the beginning of the nineteenth century, these were not designed to assist people with disabilities, since these were excluded by society. Today this view of society has changed and these people are increasingly embedded in the context of society, including in the cultural field. The 
accessibility in historic buildings is also important to safeguard the memory of the place, as the buildings are part of rail history the city access to them is important, hence the need to adapt these buildings.

At the time of construction, there was concern about affordability, but today the trend is to undo the existing architectural barriers, create opportunities for access to people with physical and sensory limitations, adapting the buildings to the new social culture and thus facilitate the recovery of memory the railroad. The historic buildings have to adapt to new uses and meet the legislation in force, promoting discrimination, without creating social exclusion.

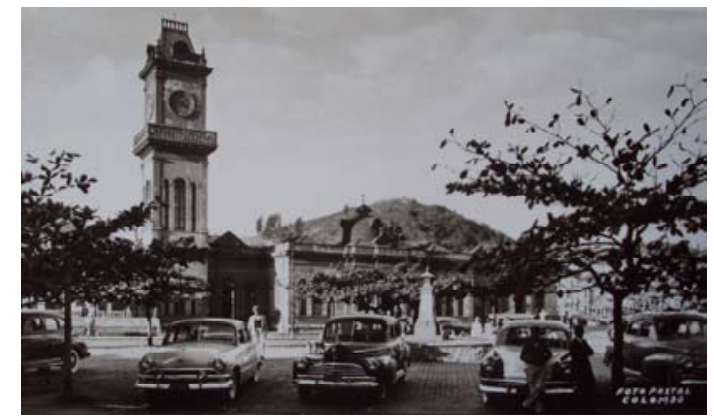

Fig. 1. Central Station in early nineteenth century. Source: Personal Archive.

The equality stated in the Universal Declaration of Human Rights [4], as a fundamental principle, where everyone has the right to accessibility to all goods and services. When we refer to accessibility faced with numerous concepts, so this study will be restricted to ergonomic studies of rail accessibility in historic buildings. However, "Accessibility is not only linked to physical factors-spatial, but also the political, social and cultural aspects that influence the achievement of desired activities" [5].

With the global cultural change, the buildings of the stations studied here, public buildings, it should allow access of to all the people, eliminating the physical barriers exist without creating distinction. In order to have an improvement in this situation, all must be aware, especially public institutions, active managers. This paper aims to draw attention to the needs access adaptation to historic railway stations, encouraging studies in the area of historical and cultural heritage in order to preserve the memory and history of these buildings, where we was studied the adaptability. It is intended through these specific objectives, an appreciation of the heritage railway, and the rescue of cultural, architectural and environmental.
The impact of non-adaptation of spaces, is only perceived by the affected, the other so-called "normal people" does not pay attention to these crucial details. The difficulty of inserting political incentive is therefore due to doesn't the commitment by the majority, making difficult the deployment of new access.

\section{Field Studies}

To develop the research, are used data obtained through direct documentation, field research and simulation of accessibility by people with disabilities (mobility, visual). Was identified possibility of adapting the property for the access of people with special needs, serving the law specifies, however there is still a failure in terms of cultural adaptation

\section{Final Considerations}

It is hoped that this work will encourage further research and acknowledge new research, involving professionals and enabling the development of other jobs in other historic buildings of the city suffering from neglect and remain inaccessible to a portion of the population.

The objective proposed here is to facilitate the improvement of urban life through architectural intervention that allows the interaction of the individual, through urban settings concerned with public space, for a better quality of life and user comfort, analyze areas of railway environment, correlating the data analyzed in the context of a place seeking revitalization strategy for these degraded areas of Juiz de Fora, favoring its dynamism and its sustainability.

Given these considerations by providing access to all public and concomitantly allowing ergonomic improvements and built environments can generate a better quality of svideo those with special needs and contributing to the diversification of uses, valuing the building and reducing the dropout these areas.

\section{References}

[1] Esteves, Albino. Álbum do Município de Juiz de Fora. Belo Horizonte: Imprensa Oficial do Estado de Minas Gerais, 1915.

[2] Oliveira, P. História de Juiz de Fora. $2^{a}$ edição. Juiz de Fora: Gráfica Comércio e Indústria Ltda. 1966.

[3] Cury. Isabelle (org). Cartas Patrimoniais. Rio de Janeiro: IPHAN, Edições do Patrimônio, 2004, p. 217-234.

[4] ONU, Organização das Nações Unidas. Declaração Universal dos Direitos Humanos. 1948. 
[5] Oliveira, A. S. D. A.; ELY, V. H. M. Bins. Avaliação das condições de acessibilidade espacial em Centro Cultural: estudo de caso. In: Encontro Nacional de Tecnologia no Ambiente Construído, 11. 2006. Florianópolis. Anais. Disponível em: $<$ http://www.arq.ufsc.br>. Acessado em: 12 set. 2011. 